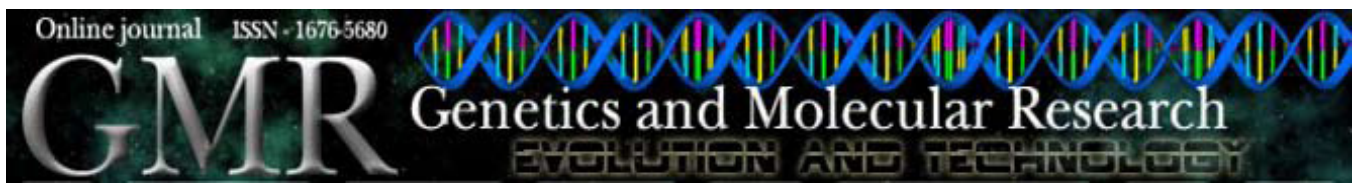

\title{
Lack of association of ACE gene I/D polymorphism with obstructive sleep apnea syndrome in Turkish patients
}

\author{
T. Yakut ${ }^{1}$, M. Karkucak ${ }^{1}$, A. Ursavas ${ }^{2}$, T. Gulten ${ }^{1}$, B. Burgazlioglu², \\ O. Gorukmez ${ }^{1}$ and M. Karadag ${ }^{2}$ \\ ${ }^{1}$ Department of Medical Genetics, Medical Faculty, \\ Uludag University, Bursa, Turkey \\ ${ }^{2}$ Department of Pulmonary Medicine, Medical Faculty, \\ Uludag University, Bursa, Turkey \\ Corresponding author: T. Yakut \\ E-mail: tyakut@uludag.edu.tr
}

Genet. Mol. Res. 9 (2): 734-738 (2010)

Received January 5, 2010

Accepted February 20, 2010

Published April 20, 2010

DOI 10.4238/vol9-2gmr755

\begin{abstract}
Angiotensin-converting enzyme (ACE) is a vital enzyme in the renin-angiotensin-aldosterone system, and there are reports in the literature describing its role in the development of cardiovascular system diseases, with I/D polymorphism of the ACE gene. We examined the relationship between a patient group with obstructive sleep apnea syndrome (OSAS) and a control group in terms of I/D polymorphism of the ACE gene. We examined 64 patients, with 37 individuals serving as the control group. PCR was used to detect ACE I/D gene polymorphism. Genotype was determined according to the bands that formed on agarose gel electrophoresis. Among the 64 OSAS patients, 27 were identified with the ID genotype, 27 with the DD genotype and 10 with the II genotype; among the 37 control subjects, 19 were identified with the ID genotype, 11 with the DD genotype and 7 with the II genotype. When the case group and controls were compared in terms of ID, II and DD genotypes, no significant difference was observed. On the other hand, when the two groups were compared with respect to mean body
\end{abstract}


mass index, the OSAS group was found to be significantly different from the control group $(\mathrm{P}=0.009)$. We conclude that ACE I/D gene polymorphism is not a genetic risk factor for OSAS in Turkish patients.

Key words: Polymorphism; ACE gene; Obstructive sleep apnea syndrome

\section{INTRODUCTION}

Obstructive sleep apnea syndrome (OSAS) is characterized by repetitive episodes of upper respiratory tract obstruction during sleep and frequent decrease in arterial oxygen saturation, and its prevalence in a community is determined to be $3.9 \%$ among men and $1.2 \%$ among women at ages of 20 to 100 years. It is reported to be a disease that is more prevalent than asthma and diabetes mellitus among adults (Ursava and Ege, 2003; Yavuz et al., 2008; Ahmadi et al., 2009). Among patients with OSAS, there is an increased incidence of various cardiovascular diseases including hypertension, stroke, acute myocardial infarct, and arrhythmia complications, and it has been shown to be related to cardiovascular mortality-morbidity rate (Barceló et al., 2001; Yaggi et al., 2005).

Angiotensin-converting enzyme (ACE) is a vital enzyme in the renin-angiotensin-aldosterone system, and is reported to play a role in the development of cardiovascular system diseases with I/D polymorphism of the ACE gene (Butler et al., 1997; Candy et al., 1999; Agerholm-Larsen et al., 2000). There are reports that individuals with the $\mathrm{D}$ allele and especially the DD genotype are prone to hypertension (O'Donnell et al., 1998; Bengtsson et al., 1999).

To date, there are no published studies of the ACE I/D gene polymorphism in relation to OSAS risk in Turkish patients with OSAS. The aim of this study was to determine the relationship between a group of patients with OSAS $(\mathrm{AHI} \geq 5)$ and a control group $(\mathrm{AHI}<5)$ in terms of I/D polymorphism of the ACE gene.

\section{MATERIAL AND METHODS}

\section{Patients}

This study involved 101 individuals who were classified based on the apnea-hypopnea index (AHI) determined by a standard polysomnography conducted by the Thoracic Diseases Department of the School of Medicine at Uludag University. The sum of apnea and hypopnea episodes was divided by the total sleep time to obtain the AHI score. Patients with AHI $\geq 5$ were considered to have OSAS. Subjects with AHI $<5$ were included in the control group. Among these cases, 64 formed the OSAS group while 37 cases formed the control group. Demographic characteristics (age, gender) and body mass index (BMI) were noted for all individuals. The study was approved by the local Ethics Committee.

\section{Methods}

Blood samples were obtained in EDTA tubes both from the patients and controls. DNA was isolated according to the Dr. Zeydanlı DNA isolation kit procedure and then stored at $-20^{\circ} \mathrm{C}$ until polymerase chain reaction (PCR) was performed. The ACE I/D gene polymor- 
phism from DNA samples was determined using the PCR technique.

The primers used to determine the ACE I/D polymorphism were F: 5'-CTG GAG ACC ACT CCC ATC CTT TCT-3' and R: 5'-GAT GTG GCC ATC ACA TTC GTC AGA T-3', and the DD genotype insertion area specific primer: F: 5'-TGG GAC CAC AGC GCC CGC CCG CCA CTA C-3' and R: 5'-TCG CCA GCC CTC CCA TGC CCA TAA-3' (Lee and Tsai, 2002). A PCR mixture of $30 \mu \mathrm{L}$ was prepared for the ACE gene amplication from DNA samples. The mixture was prepared to contain $2.5 \mu \mathrm{L}$ 10X Taq polymerase buffer, $0.5 \mu \mathrm{L} 10 \mathrm{mM}$ dNTP mixture, $2 \mu \mathrm{L}$ $25 \mathrm{mM} \mathrm{MgCl}, 1 \mu \mathrm{L} 10 \mathrm{pmol}$ primary couple, $0.2 \mu \mathrm{L}$ Taq polymerase (Bioron) and $20 \mu \mathrm{L} \mathrm{ddH}_{2} \mathrm{O}$ for each sample. About $3 \mu \mathrm{L}$ (100 ng) DNA sample was added to the mixture. To prevent wrong DD genotyping in samples of the ACE DD genotype, the results were confirmed with a second PCR analysis. PCR conditions were as follows: a first denaturation for $5 \mathrm{~min}$ at $94^{\circ} \mathrm{C}$, followed by a second denaturation for $1 \mathrm{~min}$ at $94^{\circ} \mathrm{C}$, which continued with 35 cycles that consisted of annealing for $1 \mathrm{~min}$ at $57^{\circ} \mathrm{C}$ (for verification of the $\mathrm{DD}$ genotype, at $63^{\circ} \mathrm{C}$ ), and extension for 1 min at $72^{\circ} \mathrm{C}$, which ended with final extension for $10 \mathrm{~min}$ at $72^{\circ} \mathrm{C}$.

After PCR, the samples were separated by $2 \%$ agarose gel electrophoresis, stained with ethidium bromide and photographed for the amplification study. As a result of the amplification study, the agarose gel showed an amplification band of $190 \mathrm{bp}$ in samples with the DD genotype, bands of 490 and $190 \mathrm{bp}$ in samples with the ID genotype and a band of $490 \mathrm{bp}$ in samples with the II genotype. In the second PCR analysis conducted for DD confirmation, an amplification band of 335 bp was observed with samples that had the insertion band.

\section{Statistical analysis}

All data are reported as means \pm standard deviations. The SPSS 13.0 program was used for the analysis. The Mann-Whitney test was used for comparisons made between the groups in terms of BMI and age, while the chi-square test was used for comparison of ACE gene polymorphism. A P value of $<0.05$ was accepted to be statistically significant.

\section{RESULTS}

In this study, among the 64 cases in the patient group (53 males and 11 females), the average age was $50.37 \pm 11.2$ years, and among the 37 cases in the control group (26 males and 11 females), the average age was $49.97 \pm 10.4$ years. The average BMI was found to be significantly different between the patient group with OSAS $\left(30.64 \pm 4.3 \mathrm{~kg} / \mathrm{m}^{2}\right)$ and the control group $\left(28.51 \pm 4.6 \mathrm{~kg} / \mathrm{m}^{2}\right)(\mathrm{P}=0.009)$ (Table 1).

\begin{tabular}{lccl}
\multicolumn{4}{l}{ Table 1. Clinical characteristics of obstructive sleep apnea syndrome $(\mathrm{OSAS})$ patients and the control group. } \\
\hline & OSAS patients $(\mathrm{AHI} \geq 5)(\mathrm{N}=64)$ & Control group $(\mathrm{AHI}<5)(\mathrm{N}=37)$ & $\mathrm{P}$ \\
\hline Gender $($ male/female $)$ & $53 / 11$ & $26 / 11$ & $\mathrm{P}>0.05$ \\
BMI $\left(\mathrm{kg} / \mathrm{m}^{2}\right)$ & $30.64 \pm 4.3$ & $28.51 \pm 4.6$ & $\mathrm{P}=0.009$ \\
Age (years) & $50.37 \pm 11.2$ & $49.97 \pm 10.4$ & $\mathrm{P}>0.05$ \\
\hline
\end{tabular}

$\mathrm{AHI}=$ apnea-hypopnea index; $\mathrm{BMI}=$ body mass index.

No significant differences in allele and genotype frequencies for any polymorphism were observed between patients and controls, although the $\mathrm{D}$ allele was more frequent in patients $(\mathrm{P}>0.05)$ (Table 2). 


\begin{tabular}{|c|c|c|c|c|}
\hline & OSAS patients $(\mathrm{AHI}>5)(\mathrm{N}=64)$ & Control group $(\mathrm{AHI}<5)(\mathrm{N}=37)$ & OR $(95 \% \mathrm{CI})$ & $\mathrm{P}$ \\
\hline II genotype & 10 & 7 & $0.79(0.24-2.61)$ & $\mathrm{P}>0.05$ \\
\hline ID genotype & 27 & 19 & $0.69(0.28-1.69)$ & $\mathrm{P}>0.05$ \\
\hline DD genotype & 27 & 11 & $1.72(0.67-4.48)$ & $\mathrm{P}>0.05$ \\
\hline I allele $(\%)$ & $47(37 \%)$ & $33(45 \%)$ & $0.79(0.43-1.46)$ & $\mathrm{P}>0.05$ \\
\hline $\mathrm{D}$ allele $(\%)$ & $81(63 \%)$ & $41(55 \%)$ & & \\
\hline
\end{tabular}

Regarding the I/D polymorphism of the ACE gene in the study, among the 64 OSAS patients, 27 were identified with the ID genotype, 27 with the DD genotype, and 10 with the II genotype. Among the 37 individuals in the control group, 19 were identified with the ID genotype, 11 with the DD genotype and 7 with the II genotype. In the patient group, the frequency of the I allele was $37 \%$ and the frequency of the $\mathrm{D}$ allele was $63 \%$, and in the control group the frequency of the I allele was determined to be $45 \%$ and the frequency of the D allele was $55 \%$.

\section{DISCUSSION}

In the 1990's, the renin-angiotensin-aldosterone system, especially angiotensin II, was shown to play an important role in the pathogenesis of cardiovascular and kidney diseases. ACE catalyzes the conversion of angiotensin I to angiotensin II, and its serum activity has been shown to account for some cardiovascular diseases. It has been reported that the I/D polymorphism of the ACE gene (Nakai et al., 1994; Schunkert et al., 1994) contributing to ACE serum activity may have a relationship with the development of cardiovascular diseases (Raynolds et al., 1993; Seckin et al., 2006).

In our study, we investigated the relationship between the ACE polymorphism with a group of Turkish OSAS patients and a control group. No significant difference was found between the OSAS group and the control group in terms of genotype and allele frequency (P $>0.05$ ). Similarly, in an ACE I/D polymorphism analysis among the OSAS patients, it was observed that there is no difference between patient and control groups in terms of I/D polymorphism distribution (Barceló et al., 2001; Rubinsztajn et al., 2004; Patel et al., 2007). In our literature search, we found that only Xiao et al. (1999) showed that the frequency of the I allele is significantly higher in OSAS patients. Contrary to the study of Xiao et al., we found no significant difference in allele frequency of the ACE I/D polymorphism among OSAS patients (Barceló et al., 2001; Rubinsztajn et al., 2004; Patel et al., 2007).

On the other hand, when we compared the groups in terms of BMI, a statistically significant difference was determined between patient and control groups $(\mathrm{P}=0.009)$. The BMI of the OSAS group was higher when compared with the individuals in the control group. The BMI results for OSAS patients showed similarity with those of other polymorphism studies (Barceló et al., 2001; Rubinsztajn et al., 2004; Sakai et al., 2005; Piérola et al., 2007).

Further studies of patients in larger numbers and of different ethnic backgrounds may be necessary to elucidate the association between the ACE I/D gene polymorphism and increased risk of OSAS.

\section{REFERENCES}

Agerholm-Larsen B, Nordestgaard BG and Tybjaerg-Hansen A (2000). ACE gene polymorphism in cardiovascular disease: meta-analyses of small and large studies in whites. Arterioscler. Thromb. Vasc. Biol. 20: 484-492. 
Ahmadi N, Shapiro GK, Chung SA and Shapiro CM (2009). Clinical diagnosis of sleep apnea based on single night of polysomnography vs. two nights of polysomnography. Sleep Breath. 13: 221-226.

Barceló A, Elorza MA, Barbé F, Santos C, et al. (2001). Angiotensin converting enzyme in patients with sleep apnoea syndrome: plasma activity and gene polymorphisms. Eur. Respir. J. 17: 728-732.

Bengtsson K, Orho-Melander M, Lindblad U, Melander O, et al. (1999). Polymorphism in the angiotensin converting enzyme but not in the angiotensinogen gene is associated with hypertension and type 2 diabetes: the Skaraborg Hypertension and Diabetes Project. J. Hypertens. 17: 1569-1575.

Butler R, Morris AD and Struthers AD (1997). Angiotensin-converting enzyme gene polymorphism and cardiovascular disease. Clin. Sci. 93: 391-400.

Candy GP, Skudicky D, Mueller UK, Woodiwiss AJ, et al. (1999). Association of left ventricular systolic performance and cavity size with angiotensin-converting enzyme genotype in idiopathic dilated cardiomyopathy. Am. J. Cardiol. 83: 740-744.

Lee YJ and Tsai JC (2002). ACE gene insertion/deletion polymorphism associated with 1998 World Health Organization definition of metabolic syndrome in Chinese type 2 diabetic patients. Diabetes Care 25: 1002-1008.

Nakai K, Itoh C, Miura Y, Musya T, et al. (1994). Deletion polymorphism of the angiotensin I-converting enzyme gene associates with increased risk for ischemic heart diseases in the Japanese. Rinsho Byori 42: 689-694.

O’Donnell CJ, Lindpaintner K, Larson MG, Rao VS, et al. (1998). Evidence for association and genetic linkage of the angiotensin-converting enzyme locus with hypertension and blood pressure in men but not women in the Framingham Heart Study. Circulation 97: 1766-1772.

Patel SR, Larkin EK, Mignot E, Lin L, et al. (2007). The association of angiotensin converting enzyme (ACE) polymorphisms with sleep apnea and hypertension. Sleep 30: 531-533.

Piérola J, Barceló A, de la Peña M, Barbé F, et al. (2007). Beta3-adrenergic receptor Trp64Arg polymorphism and increased body mass index in sleep apnoea. Eur. Respir. J. 30: 743-747.

Raynolds MV, Bristow MR, Bush EW, Abraham WT, et al. (1993). Angiotensin-converting enzyme DD genotype in patients with ischaemic or idiopathic dilated cardiomyopathy. Lancet 342: 1073-1075.

Rubinsztajn R, Kumor M, Byskiniewicz K and Chazan R (2004). Angiotensin-converting enzyme gene polymorphism in patients with obstructive sleep apnea. Pol. Arch. Med. Wewn. 112: 817-822.

Sakai K, Takada T, Nakayama H, Kubota Y, et al. (2005). Serotonin-2A and 2C receptor gene polymorphisms in Japanese patients with obstructive sleep apnea. Intern. Med. 44: 928-933.

Schunkert H, Hense HW, Holmer SR, Stender M, et al. (1994). Association between a deletion polymorphism of the angiotensin-converting-enzyme gene and left ventricular hypertrophy. N. Engl. J. Med. 330: 1634-1638.

Seckin D, Ilhan N, Ilhan N and Ozbay Y (2006). The relationship between ACE insertion/deletion polymorphism and coronary artery disease with or without myocardial infarction. Clin. Biochem. 39: 50-54.

Ursavaş A and Ege E (2003). Obstructive sleep apnea and cardiovascular diseases. Anadolu. Kardiyol. Derg. 3: 150-155.

Xiao Y, Huang X, Qiu C, Zhu X, et al. (1999). Angiotensin I-converting enzyme gene polymorphism in Chinese patients with obstructive sleep apnea syndrome. Chin. Med. J. 112: 701-704.

Yaggi HK, Concato J, Kernan WN, Lichtman JH, et al. (2005). Obstructive sleep apnea as a risk factor for stroke and death. N. Engl. J. Med. 353: 2034-2041.

Yavuz Z, Ursavas A, Ege E, Ozarda IY, et al. (2008). Homocysteine levels in patients with obstructive sleep apnea syndrome. Tuberk. Toraks 56: 37-42. 